\title{
Comparability of a Three-Dimensional Structure in Biopharmaceuticals Using Spectroscopic Methods
}

\author{
Víctor Pérez Medina Martínez, ${ }^{1}$ Mario E. Abad-Javier, ${ }^{2}$ \\ Alexis J. Romero-Díaz, ${ }^{1}$ Francisco Villaseñor-Ortega, ${ }^{2}$ \\ Néstor O. Pérez, ${ }^{1}$ Luis F. Flores-Ortiz, ${ }^{1}$ and Emilio Medina-Rivero ${ }^{1}$ \\ ${ }^{1}$ Unidad de Investigación y Desarrollo, Probiomed S.A. de C.V. Cruce de Carreteras Acatzingo-Zumpahuacán S/N, \\ Tenancingo, 52400 Mexico, MEX, Mexico \\ ${ }^{2}$ Departamento de Ingeniería Bioquímica, Instituto Tecnológico de Celaya, Avenida Tecnológico y Antonio García Cubas S/N, \\ 38010 Celaya, GTO, Mexico
}

Correspondence should be addressed to Luis F. Flores-Ortiz; luis.flores@probiomed.com.mx and Emilio Medina-Rivero; emilio.medina@probiomed.com.mx

Received 17 February 2014; Accepted 23 April 2014; Published 22 May 2014

Academic Editor: Josep Esteve-Romero

Copyright (C) 2014 Víctor Pérez Medina Martínez et al. This is an open access article distributed under the Creative Commons Attribution License, which permits unrestricted use, distribution, and reproduction in any medium, provided the original work is properly cited.

\begin{abstract}
Protein structure depends on weak interactions and covalent bonds, like disulfide bridges, established according to the environmental conditions. Here, we present the validation of two spectroscopic methodologies for the measurement of free and unoxidized thiols, as an attribute of structural integrity, using 5, $5^{\prime}$-dithionitrobenzoic acid (DTNB) and DyLight Maleimide (DLM) as derivatizing agents. These methods were used to compare Rituximab and Etanercept products from different manufacturers. Physicochemical comparability was demonstrated for Rituximab products as DTNB showed no statistical differences under native, denaturing, and denaturing-reducing conditions, with Student's $t$-test $P$ values of $0.6233,0.4022$, and 0.1475 , respectively. While for Etanercept products no statistical differences were observed under native $(P=0.0758)$ and denaturing conditions $(P=$ $0.2450)$, denaturing-reducing conditions revealed cysteine contents of $98 \%$ and $101 \%$, towards the theoretical value of 58 , for the evaluated products from different Etanercept manufacturers. DLM supported equality between Rituximab products under native $(P=0.7499)$ and denaturing conditions $(P=0.8027)$, but showed statistical differences among Etanercept products under native conditions $(P<0.001)$. DLM suggested that Infinitam has fewer exposed thiols than Enbrel, although DTNB method, circular dichroism (CD), fluorescence (TCSPC), and activity (TNF $\alpha$ neutralization) showed no differences. Overall, this data revealed the capabilities and drawbacks of each thiol quantification technique and their correlation with protein structure.
\end{abstract}

\section{Introduction}

Rituximab and Etanercept are biopharmaceutical recombinant proteins used for the treatment of non-Hodgkin lymphoma and rheumatoid arthritis [1,2]; and as a monoclonal antibody and a fusion protein they are composed of a pair of heavy and light chains and a homodimer with several cysteines, respectively. Both proteins are assembled with interand intrachain disulfide bonds that are established during their biosynthesis in the endoplasmic reticulum of recombinant $\mathrm{CHO}$ cells [3-5]. Once folded, glycosylated within the cell, and secreted into culture medium, recombinant proteins can be subjected to physicochemical stress, either during their residence in the cell culture media or during the steps of purification, formulation, filling, and storage, which stem mainly from changes in $\mathrm{pH}$, temperature, and ionic strength $[6,7]$. The degree of modification determines the stability of the protein, which may expose buried cysteine residues or broken disulfide bridges, allowing for the measurement of the free thiols as a quality attribute for ensuring the safety and efficacy of a biopharmaceutical product. During the last years spectroscopic techniques used for recombinant protein characterization are gaining interest in order to identify specific structural properties, folding phenomena, and stability based 
on the absorptivity response, fluorescence, and light dispersion effects [8-10].

Several protocols for quantifying free thiols have been described in the past to study protein structure and stability. That is the case of Ellman's technique, first described in 1959 [11]. However, to the best of our knowledge, there are no validation protocols and criteria for the measurement of free thiols in biopharmaceuticals, and there is no correlation between the structural conditions and biological activity of the biotherapeutic protein and their exposure of thiol groups.

Colorimetric methods, like 5,5'-dithionitrobenzoic acid (DTNB), are useful to analyze free thiols above the nanomolar range but at the expense of large protein quantities $[12,13]$. To overcome this, DyLight Maleimide (DLM) can be used for the nanomolar range [14], taking advantage of their fluorescence properties and selectivity against thiol groups, well known for Maleimides [15, 16]. Both orthogonal techniques can provide a wider concentration range for thiol analysis and a verification of the total content or trend observed for a protein, when analyzed under different conditions.

Native, denaturing, and denaturing-reducing conditions allow for the quantification of the free cysteine's thiols coming from degradation, unfolding, or broken disulfide bridges buried in the protein and the total cysteines content within the protein, respectively. In every case, a correlation against the integrity of the protein structure can be done by the use of spectroscopic techniques such as circular dichroism (CD) [15] and intrinsic fluorescence lifetime measured by timecorrelated single photon counting method (TCSPC) [16]. Protein identity and oxidation can be tested from the comparison of the theoretical content of cysteines that comes from the amino acid sequence. This information together contributes to the physicochemical characterization and the establishment of quality attributes and comparability criteria among products.

The use of suitable methodologies for intended purpose, mentioned before, plays an essential role in biopharmaceutical companies, as they are feasible tools for bioprocess development, formulations design, and stability studies in order to define product shelf life.

Here we present a physicochemical comparability study using two orthogonal thiol quantification methods, correlated with other spectroscopic and biological methods, and its validation. Troubleshooting is given for both techniques.

\section{Materials and Methods}

2.1. Reagents. L-cysteine $\mathrm{HCl}$, Ellman's reagent, DyLight 488 Maleimide, and Slide-A dialysis cassettes were obtained from Thermo Scientific (Cincinnati, OH, USA). Monobasic and dibasic sodium phosphate, sodium citrate, citric acid, mannitol, sucrose, and sodium azide were obtained from J. T. Baker (Center Valley, PA, USA). EDTA, dithiothreitol (DTT), guanidine hydrochloride $(\mathrm{GdnHCl})$, Tris-HCL, polysorbate 80 , crystal violet, dimethyl sulfoxide (DMSO), phenylisothiocyanate (PIT), and heat inactivated fetal calf serum were obtained from Sigma-Aldrich (Saint Louis, MO, USA). Human serum complement was obtained from Quindel
(San Diego, CA, USA); Somatropine CRS (Batch 3, Code: 50947000, Id: O12YRG) was obtained from EDQM Ph. Eur (Strasbourg, France). Human serum albumin (HSA) batch 4330200029 was purchased from CSL Behring AG (King of Prussia, PA, USA). Glatiramer acetate (GA) batch AGPP12001 was obtained from Probiomed S.A. de C.V. (Mexico City, Mexico) and $10 \mathrm{kD}$ protein Marker part number A26487 for cIEF batch M205297 was obtained from Beckman Coulter (Brea, CA, USA). DMEM medium supplemented with glutamine $6 \mathrm{mM}$ and pyruvate $1 \mathrm{mM}$ was obtained from Gibco, Life Technologies (Waltham, MA, USA). A375 human melanoma and WIL2-S lymphoma cell lines were purchased from ATCC (Manassas, VA, USA) and maintained in a humidified chamber at $37^{\circ} \mathrm{C}$ with $5 \% \mathrm{CO}_{2}$.

NAP-5 Gel filtration columns were obtained from GE Healthcare (Buckinghamshire, UK). $30 \mathrm{kDa}$ centricons were obtained from EMD Millipore (Billerica, MA, USA). Neuraminidase was obtained from New England Biolabs (Ipswich, MA, USA). Mabthera batches, B60360, B60420, B60480, B60490, B6074B04, and B6083, were obtained from F. Hoffmann-La Roche Ltd. (Basel, Switzerland). Enbrel batches, 34359, 1027881, 1030760, G18414, F65452, and F40596, were obtained from Amgen Inc. (Thousand Oaks, CA, USA). Kikuzubam batches, 5445110403, 5433120509, and 5445100901, and Infinitam (drug substance) batches, ETPP12001, ETPP12002, ETPP12003, and ETPP12005 from Probiomed S.A. de C.V. (Mexico City, Mexico) were used for the study.

2.2. Instrumentation. A DU640 UV-Vis Spectrophotometer from Beckman Coulter Inc. (Brea, CA) and a Nanodrop 2000 UV-Vis Spectrophotometer from Thermo Fisher Scientific Inc. (Waltham, MA) were used for DTNB and protein concentration determinations. A Fluorolog 3 spectrofluorometer from Horiba Jobin Yvon (Kyoto, Japan), equipped with a Xenon arc lamp of $450 \mathrm{~W}$, was used to obtain fluorescence data (steady state). All sample incubation treatments were carried on a Thermomixer Comfort from Eppendorf AG (Hamburg, Germany). Structural analyses were performed in a Circular Dichroism J-815 spectrometer from Jasco International Co. Ltd. (Tokyo, Japan). Intrinsic Trp fluorescence lifetime measured by time-correlated single photon counting (TCSPC) was performed using a $288 \mathrm{~nm}$ pulsed diode light source, with pulse duration $<1.2 \mathrm{~ns}$. Right angle emission was detected at $333 \mathrm{~nm}$ with $1 \mathrm{MHz}$ rate using a Fluorolog 3 spectrofluorometer from Horiba Jobin Yvon. Bioassays absorbance was measured using Spectramax Plus384 microplate spectrophotometer from Molecular Devices (Sunnyvale, CA) using Soft Max Pro software.

\subsection{Methods}

2.3.1. Placebos. Placebo used for Rituximab included $\mathrm{NaCl}$ $150 \mathrm{mM}$ and $0.14 \mathrm{mM}$ polysorbate 80 in citrate buffer $29 \mathrm{mM}$ $\mathrm{pH}$ 6.5, while placebo used for Etanercept was manitol $22 \mathrm{mM}$ and sucrose $3 \mathrm{mM}$ in $10 \mathrm{mM}$ Tris buffer $\mathrm{pH}$ 7.4.

2.3.2. Sample Preparation. Protein samples were concentrated up to $100 \mathrm{mg} \cdot \mathrm{mL}^{-1}$ and dialyzed against their corresponding placebos using $30 \mathrm{kDa}$ centricons spin columns at 
14,000 $\mathrm{g}$ for $15 \mathrm{~min}$. Etanercept samples for the analysis under denaturing-reducing conditions were additionally digested with Neuraminidase using $20 \mathrm{U}$ per mg of protein. Protein concentration was therefore adjusted to $20,7.5$ and $1 \mathrm{mg} \cdot \mathrm{mL}^{-1}$ for native, denaturing, and denaturing-reducing conditions for DTNB method, respectively. $100 \mathrm{mM}$ sodium phosphate and $5 \mathrm{mM}$ EDTA buffer solution at $\mathrm{pH} 8.0$ were used for DTNB method and $100 \mathrm{mM}$ sodium phosphate, $150 \mathrm{mM}$ sodium chloride, and $5 \mathrm{mM}$ EDTA buffer solution at $\mathrm{pH} 7.0$ were used for DLM method. Protein concentration for DLM method was adjusted to $1 \mathrm{mg} \cdot \mathrm{mL}^{-1}$ either under native or denaturing conditions. For denaturing conditions of both methods PBS with $\mathrm{GdnHCl}$ was added to samples to give a final concentration of $5 \mathrm{M}$, while for denaturing-reducing conditions $\mathrm{GdnHCl}$ was taken up to $7.2 \mathrm{M}$ and $10 \mathrm{mM}$ DTT, and samples were incubated for $30 \mathrm{~min}$ at $30^{\circ} \mathrm{C}$. Once samples were reduced, DTT was eliminated by buffer exchange with $100 \mathrm{mM}$ sodium phosphate, $5 \mathrm{mM}$ EDTA buffer solution at pH 8.0, passed over NAP-5 columns. Protein concentration under denaturing-reducing conditions was estimated at this step, prior derivatization. All solutions including placebos were degassed by sonication for $30 \mathrm{~min}$ and bubbled with nitrogen during $5 \mathrm{~min}$ prior its use, following previous reports that used argon during 15 minutes [17, 18].

Placebos were treated like samples for both methods, and absorbance and fluorescence were measured as described below.

HSA was diafiltered against purified water, using $30 \mathrm{kDa}$ centricons, until triptofanate acetate was eliminated. $1 \mathrm{mg}$ of purified HSA was treated with $2.5 \mathrm{mM}$ DTT on PBS at $\mathrm{pH} 7.0$ for $30 \mathrm{~min}$ at $22^{\circ} \mathrm{C}$. DTT was eliminated by buffer exchange with PBS at pH 7.0, in NAP-5 columns. DTT was added in order to reduce sulfenic acids from Cys 34 to sulfhydryl groups. Three independent triplicates were derivatizated with DLM.

2.3.3. Thiol Derivatization. Stock solutions of DTNB and DLM derivatization agents were diluted with DMSO. Derivatization was carried at a final concentration of $500 \mu \mathrm{M}$ of DTNB and $1 \mathrm{~h}$ incubation at $30^{\circ} \mathrm{C}$. Absorbance was measured at $412 \mathrm{~nm}$ and $280 \mathrm{~nm}$ in $1 \mathrm{~cm}$ QS quartz cuvettes [11].

DLM derivatization was carried at a final concentration of $0.125 \mathrm{mM}$ and $2 \mathrm{~h}$ incubation at $25^{\circ} \mathrm{C}$. Extensive dialysis against $100 \mathrm{mM}$ sodium phosphate, $150 \mathrm{mM}$ sodium chloride, and $5 \mathrm{mM}$ EDTA buffer solution at $\mathrm{pH}$ 7.0, (phosphate buffer solution (PBS)) using $10 \mathrm{kDa}$ Slide-A Dialysis units, was performed after derivatization. Protein concentration under native and denaturing conditions was adjusted to $1 \mathrm{mg} \cdot \mathrm{mL}^{-1}$ using $100 \mathrm{mM}$ sodium phosphate, $150 \mathrm{mM}$ sodium chloride, $5 \mathrm{mM}$ EDTA buffer, and GdnHCl $5 \mathrm{M}$ solution at $\mathrm{pH}$ 7.0. DLM fluorescence emission was measured at $518 \mathrm{~nm}$, exciting at $493 \mathrm{~nm}$ in $3 \mathrm{~mm}$ QS quartz cuvettes at $25^{\circ} \mathrm{C} \pm 1^{\circ} \mathrm{C}$ as previous studies recommended $[14,19,20]$.

2.3.4. Rituximab, Etanercept, and Glatiramer Acetate Amine Neutralization under Native Conditions. To neutralize amines under native conditions, $50 \mu \mathrm{L}$ of a mixture $50: 50$ $(\mathrm{v} / \mathrm{v})$ phenyl isothiocyanate, DMSO, was added into 10 aliquots of $5 \mu \mathrm{L}$ with continuous stirring to $0.4 \mathrm{~mL}$ of a solution at $2.5 \mathrm{mg} / \mathrm{mL}$ of protein in carbonate buffer $(0.1 \mathrm{M}$ $\mathrm{pH}$ 9.0). Samples were incubated at $5 \pm 3^{\circ} \mathrm{C}$ for $8 \mathrm{~h}$, in the dark. Afterwards, the buffer was exchanged with $15 \mathrm{mM}$ sodium azide in PBS using NAP-5 columns recommended by [21]. Samples were derivatized with DLM as described before (see Section 2.3.3).

2.3.5. DLM Nonspecific Interaction with Rituximab, Etanercept, and Glatiramer Acetate under Native Conditions. Prior derivatization, DLM was taken from a stock solution at $12.5 \mathrm{mM}$ and was allowed to react with $50 \mu \mathrm{L}$ of $50 \mathrm{mM}$ cysteine in PBS for two hours at $25^{\circ} \mathrm{C}, 600 \mathrm{rpm}$. Sample preparation and derivatization were done as described using cysteine reacted with DLM instead of DLM (Sections 2.3.2 and 2.3.3); expecting not having covalent reactions against proteins, DLM-cysteine was left to form Van der Waals or hydrophobic interactions with proteins.

2.3.6. Circular Dichroism Measurements. Circular dichroism studies were carried out in a Jasco-815 spectropolarimeter, using a modified method previously reported [15]. Etanercept and Rituximab samples were diluted to $0.1 \mathrm{mg} \cdot \mathrm{mL}^{-1}$ for farUV CD spectra $(190-300 \mathrm{~nm})$ in a $0.1 \mathrm{~cm}$ quartz cell and to $3.3 \mathrm{mg} \cdot \mathrm{mL}^{-1}$ for near-UV CD spectra $(240-350 \mathrm{~nm})$ either under native, denaturing, or denaturing-reducing conditions. Samples were diluted with $10 \mathrm{mM}$ phosphate $\mathrm{pH} 7.0$ for native conditions and with $10 \mathrm{mM}$ phosphate and $5 \mathrm{M} \mathrm{GdnHCl}$ buffer solution $\mathrm{pH} 7.0$ for denaturing conditions, while for denaturing-reducing conditions samples were treated with $10 \mathrm{mM}$ DTT for $30 \mathrm{~min}$ at $25^{\circ} \mathrm{C}$ and buffer exchanged using NAP-5 columns against $10 \mathrm{mM}$ phosphate buffer solution and $\mathrm{GdnHCl} 0.5 \mathrm{M} \mathrm{pH} 3.0$. Samples were reconstituted to $10 \mathrm{mM}$ phosphate buffer solution and $\mathrm{GdnHCl} 3 \mathrm{M}$ pH 3.0 final concentration. Spectrum was acquired as an average of 3 scans using 0.01 (far-UV CD) and $0.1 \mathrm{~cm}$ (near-UV CD) quartz cuvettes at $1 \mathrm{~nm}$ data pitch, $1 \mathrm{~nm}$ bandwidth, and $50 \mathrm{~nm} \cdot \mathrm{min}^{-1}$ of scan speed. Each condition buffer was used as blank for each spectrum.

2.3.7. Intrinsic Trp Fluorescence Lifetime (TCSPC). Measurements were done in a Fluorolog 3 spectrofluorometer from Horiba Jobin Yvon (Kyoto, Japan), equipped with a Xenon arc lamp. Etanercept samples were adjusted to $2 \mathrm{mg} \cdot \mathrm{mL}^{-1}$ with $10 \mathrm{mM}$ phosphate buffer solution at $\mathrm{pH} 7.0$ and measured. Data analysis for TCSPC was done using DAS6 software; fitting results were adjusted using 2 exponential decays for least squares regression. Fluorescence lifetime was obtained as amplitude weighted mean of exponential decays [16].

2.3.8. CDC Bioassays with Rituximab. This bioassay was performed as Brezski and collaborators [22] with minor changes. Briefly, cell antiproliferation was induced by Rituximab through complement-dependent cytotoxicity (CDC) to CD20 expressing cells (WIL2-S, ATCC CRL-8885) in the presence of human serum complement (Quidel, CA, USA). Cells viability, following CDC treatment with Rituximab, was 
TABLE 1: Validation results for DTNB and DLM methods.

\begin{tabular}{|c|c|c|c|}
\hline \multirow{2}{*}{ Validation test } & \multirow{2}{*}{ Acceptance criteria } & \multicolumn{2}{|c|}{ Method result } \\
\hline & & DTNB & DyLight 488 \\
\hline Precision (repeatability) & $<20 \%$ & $\begin{array}{l}\text { RSD: } 2.52 \% \\
\text { (denaturing-reducing conditions). } \\
\text { RSD: } 17.3 \% \text { (native conditions). }\end{array}$ & $\begin{array}{l}\text { RSD: NT\% } \\
\text { (denaturing-reducing } \\
\text { conditions). } \\
\text { RSD: } 13.3 \% \text { (native conditions). }\end{array}$ \\
\hline Accuracy & $\begin{array}{c}\text { Total recovery between } 95 \\
\text { and } 105 \% \text { in respect to } \\
\text { theoretical value. }\end{array}$ & $\begin{array}{l}\text { 99.5\% recovery using Somatropin } \\
\text { (Cys/Protein ratio } 3.98 \text { ) }\end{array}$ & $\begin{array}{l}\text { 101.0\% recovery using HSA } \\
\text { (Cys/Protein ratio } 1.01)\end{array}$ \\
\hline Intermediate precision & RSD $<10 \%$ & RSD: $3.8 \%$ & RSD: $0.66 \%$ \\
\hline Linearity & $\begin{array}{c}r^{2} \geq 0.980 \\
\text { Ordinate }=0\end{array}$ & $\begin{array}{l}r^{2}=0.999 \text { native and } \\
\text { denaturing-reducing conditions. } \\
\text { Slope }=0.01285 \mu \mathrm{M}^{-1} \\
r^{2}=0.983 \text { denaturing conditions. } \\
\text { Slope }=0.0093 \mu \mathrm{M}^{-1} \\
\text { Forced through zero. }\end{array}$ & $\begin{array}{l}r^{2}=0.990 \text { native and denaturing } \\
\text { conditions. } \\
\text { Slope }=465,834 \mu \mathrm{M}^{-1} \\
\text { Forced through zero. }\end{array}$ \\
\hline Quantification limit & Report value & $5 \mu \mathrm{M}$ & $0.1 \mu \mathrm{M}$ \\
\hline Selectivity & $\begin{array}{l}\text { Cysteine-free protein has } \\
\text { the same signal of placebo. }\end{array}$ & $\begin{array}{l}\text { GA: } 0.0010 \\
\text { Placebo: } 0.0005\end{array}$ & $\begin{array}{l}\text { PM: } 0.0005 \\
\text { Placebo: } 0.0005\end{array}$ \\
\hline
\end{tabular}

NT\%: not tested.

measured using Alamar Blue probe (Promega, WI, USA). Rituximab potency was expressed against a reference standard of $100 \%$ potency.

2.3.9. Bioassays for Neutralization of TNF- $\alpha$ with Etanercept. Neutralizing activity of Etanercept over TNF- $\alpha$ was measured as the viability of A375 cell line treated with actinomycin D $[23,24]$. Cells were seeded in triplicate at $5 \times 10^{5} /$ well into a 96-well plate in DMEM medium supplemented with $10 \%$ $(\mathrm{v} / \mathrm{v}) \mathrm{FBS}$ and then were incubated for $24 \mathrm{~h}, 37^{\circ} \mathrm{C}$ at $5 \% \mathrm{CO}_{2}$. Medium containing TNF- $\alpha$ at $21 \mathrm{ng} / \mathrm{mL}$ was added to the cell culture (final concentration $7 \mathrm{ng} / \mathrm{mL}$ ); then, Etanercept dilutions within the range of 5.2 to $60.0 \mathrm{ng} / \mathrm{mL}$ and actinomycin D at $390 \mathrm{ng} / \mathrm{mL}$ (final concentration $130 \mathrm{ng} / \mathrm{mL}$ ) were added to the cell culture. Cells were incubated for additional $18 \mathrm{~h}$ at $37^{\circ} \mathrm{C}, 5.0 \% \mathrm{CO}_{2}$, and then fixed with formaldehyde $5 \%$ adding $50 \mu \mathrm{L}$ to each well and dyed with $10 \%$ violet crystal. Absorbance was measured at $540 \mathrm{~nm}$ with a $690 \mathrm{~nm}$ reference filter. The $\mathrm{ED}_{50}$ value was calculated by four-parameter logistic curve fit using Soft-Max Pro software. Enbrel value was taken as $100 \%$ potency.

\subsection{Method Validation (Table 1)}

2.4.1. System Suitability. DTNB method defined acceptance criteria were as follows. (1) Determination coefficient for Lcysteine $\mathrm{HCl}$ standard curve (5-200 $\mu \mathrm{M})$ must be $>0.980$. (2) Absorbance measurement at $412 \mathrm{~nm}$ from placebo (blank), water, and a thiol-free protein must be $<0.005 \mathrm{AU}$. (3) Cys/Protein molar ratio under denaturing-reducing conditions of somatropine CRS standard must be $4.0 \pm 0.5$.

DLM method defined acceptance criteria were as follows. (1) Determination coefficient for DLM standard curve (0.1$7.5 \mu \mathrm{M}$ ) must be $>0.980$. (2) Fluorescence measurement for placebo, water, and a thiol-free protein must be $<20,000$ CPS.

\subsubsection{Precision}

Repeatability. Sextuplicate samples at 0.4 and $1.0 \mathrm{mg} \cdot \mathrm{mL}^{-1}$ for Etanercept and Rituximab, respectively, were analyzed with DTNB and DyLight 488 Maleimide methods. The intermediate precision aws that two different analysts measured Etanercept and Rituximab samples in two different days. (Etanercept for DTNB method and Rituximab for DLM method) Relative standard deviation $\leq 10 \%$ was expected.

2.4.3. Accuracy. Triplicates of somatropine CRS and HSA at $1 \mathrm{mg} \cdot \mathrm{mL}^{-1}$ were prepared under denaturing-reducing and native conditions, respectively. HSA was treated with $2.5 \mathrm{mM}$ DTT, $30 \mathrm{~min}, 22^{\circ} \mathrm{C}$ prior analysis, in order to reduce oxidized cysteines. Recovery percentages, expected from 90 to $110 \%$ and 60 to $140 \%$, were calculated against theoretical Cys/Protein molar ratio of 4 and 1, for somatropine and HSA, respectively. Somatropine and HSA concentrations were determined from absorbance at $280 \mathrm{~nm}$, using $\varepsilon$ values of $0.82 \mathrm{~g} \cdot \mathrm{L}^{-1} \cdot \mathrm{cm}^{-1}, 0.531 \mathrm{~g} \cdot \mathrm{L}^{-1} \cdot \mathrm{cm}^{-1}$ and molecular masses of 22 , $124 \mathrm{~g} \cdot \mathrm{mol}^{-1}$ and $66,470 \mathrm{~g} \cdot \mathrm{mol}^{-1}$, respectively.

2.4.4. Specificity. Placebos, somatropine CRS at $1 \mathrm{mg} \cdot \mathrm{mL}^{-1}$, GA (negative control, thiol-free peptide) at $20 \mathrm{mg} \cdot \mathrm{mL}^{-1}$, and $10 \mathrm{kD}$ protein marker at $1 \mathrm{mg} \cdot \mathrm{mL}^{-1}$ were analyzed under denaturing-reducing and native conditions. Absorbance and fluorescence measurements according to the system suitability were expected.

2.4.5. Quantification Limit. The lowest concentration level for DTNB and DLM method curves with a RSD $<20 \%$ was established as limit of quantification.

2.4.6. Standard Curves and Linearity. Cysteine stock solutions $(1.5 \mathrm{mM})$ were done gravimetrically, diluted to $5 \mu \mathrm{M}$, 
TABLE 2: Thiol quantification using DTNB method. Rituximab and Etanercept free thiols under native, denaturing, and denaturing-reducing conditions using DTNB method. Uncertainty values are presented in SD $(n=9)$.

\begin{tabular}{lcccccc}
\hline & Condition & Mabthera & RSD & Kikuzubam & RSD & $P$ \\
\hline \multirow{3}{*}{ Rituximab } & Native & $0.0175 \pm 0.010$ & 55.0 & $0.0200 \pm 0.012$ & 58.4 & 0.6233 \\
& Denaturing & $0.602 \pm 0.117$ & 19.4 & $0.558 \pm 0.102$ & 18.4 & 0.4022 \\
& Denaturing/reducing & $31.6 \pm 0.8$ & 2.7 & $30.8 \pm 1.5$ & 4.7 & 0.1475 \\
\hline \multirow{3}{*}{ Etanercept } & Condition & Enbrel & RSD & Infinitam & RSD & $P$ \\
& Native & $0.0241 \pm 0.015$ & 61.5 & $0.0137 \pm 0.005$ & 37.6 & 0.0758 \\
& Denaturing & $0.447 \pm 0.113$ & 25.3 & $0.498 \pm 0.060$ & 12.1 & 0.2450 \\
& Denaturing/reducing & $56.6 \pm 2.5$ & 4.4 & $58.9 \pm 1.4$ & 2.4 & 0.0229 \\
\hline
\end{tabular}

$10 \mu \mathrm{M}, 25 \mu \mathrm{M}, 50 \mu \mathrm{M}, 100 \mu \mathrm{M}$, and $200 \mu \mathrm{M}$, and analyzed in triplicates using DTNB method.

DLM was incubated with PBS, $50 \mathrm{mM}$ cysteine for $2 \mathrm{~h}$ at $25^{\circ} \mathrm{C}$. Dilutions to $7.5 \mu \mathrm{M}, 5 \mu \mathrm{M}, 3.75 \mu \mathrm{M} 1.85 \mu \mathrm{M}, 1 \mu \mathrm{M}$, $0.25 \mu \mathrm{M}$, and $0.1 \mu \mathrm{M}$ were analyzed in triplicates using DLM method. DLM concentration was determined by absorbance at $493 \mathrm{~nm}$ using an extinction coefficient of $70,000 \mathrm{M}^{-1} \cdot \mathrm{cm}^{-1}$. Determination coefficient $\left(r^{2}\right)>0.980$ and slope $\neq 0$ were expected.

2.5. Statistical Analysis. Two group sample comparisons were done by unpaired and two-tailed Student's $t$-test. Homogeneity of variance was tested using $F$-max test. $t$-test comparison was calculated depending on $F$-max test, using Microsoft Excel software. Differences were considered significant at $P<$ 0.05 . Confidence intervals were calculated at $95 \%$. Error bars are depicted as standard error of mean $( \pm \mathrm{SE})$.

2.6. Thiol/Protein Ratio Calculations. For DTNB method, thiol concentration was calculated from cysteine standard curves depending on the specific condition related to the assay. Absorbance at $412 \mathrm{~nm}$ was recorded and interpolated into curve made with phosphate buffer $0.1 \mathrm{M}, \mathrm{pH} 8.0$, for native and denaturing-reducing conditions, while curve made with phosphate buffer $0.1 \mathrm{M}$ and $5 \mathrm{M} \mathrm{GdnHCl,} \mathrm{pH} \mathrm{8.0,}$ was used for denaturing conditions.

For DLM method, fluorescence at $518 \mathrm{~nm}$ was recorded and interpolated into curve. This curve was made with phosphate buffer $0.1 \mathrm{M}$ and $5 \mathrm{M} \mathrm{GdnHCl}, \mathrm{pH} 7.0$, and was used either for native or denaturing conditions.

Cysteine and protein mass of all samples were adjusted to nanomoles per sample. Cysteine nanomoles were divided by the protein nanomoles to obtain Cys/prot molar ratio. Averages of independent triplicates were reported.

\section{Results}

3.1. Native Conditions. DTNB method showed no difference between placebo (blank) and glatiramer acetate (GA) (thiol free peptide) at $20 \mathrm{mg} \cdot \mathrm{mL}^{-1}$, with absorbance values of 0.0005 and $0.0014 \mathrm{AU}$ for placebos and GA, respectively. Glatiramer acetate (GA), a random copolymer of tyrosine, lysine, alanine, and glutamic acid, was used as negative control. Fluorescence measurements about 1600 and $5000 \mathrm{cps}$ were obtained for placebo and $10 \mathrm{kDa}$ protein marker, respectively.
Linear range using L-cysteine as standard was demonstrated from $5 \mu \mathrm{M}$ to $200 \mu \mathrm{M}$ derivatizing with DTNB, while for DLM method, using DyLight 488 Maleimide linked to L-cysteine as standard, it was demonstrated from $0.1 \mu \mathrm{M}$ to $7.5 \mu \mathrm{M}$ (Table 1).

3.1.1. Rituximab. Analysis of three different batches of Mabthera and Kikuzubam shows no statistical differences for their Cys/Protein molar ratios, with $P$ values of 0.6233 and 0.7499 for DTNB and DLM methods, respectively. Cys/ Rituximab average molar ratios were 0.018 and 0.020 for Mabthera and Kikuzubam, respectively, using DTNB method with a confidence interval at $95 \%$ from 0.0253 to 0.0096 for Mabthera, while 0.064 and 0.068 average molar ratios were obtained for the products using DLM method with a confidence interval at $95 \%$ from 0.0865 to 0.0408 for Mabthera (Tables 2 and 3).

3.1.2. Etanercept. Enbrel and Infinitam showed no statistical difference with DTNB method $(P=0.0758)$, while DLM method reveals statistical differences among products $(P<$ 0.001). Cys/Etanercept average molar ratios were 0.024 and 0.014 for Enbrel and Infinitam, respectively, using DTNB method with a confidence interval at 95\% from 0.0361 to 0.0120 for Enbrel, while 0.084 and 0.047 average molar ratios were obtained for the products using DLM method with a confidence interval at $95 \%$ from 0.0978 to 0.0710 for Enbrel (Tables 2 and 3 ).

3.2. Denaturing Conditions. Like native conditions, GA was used as negative control, with its absorbance values lower than $0.002 \mathrm{AU}$, for DTNB method, while fluorescence from $10 \mathrm{kDa}$ protein marker was below $5000 \mathrm{cps}$ for DLM method (Table 4).

Linear range, using L-cysteine as standard, was demonstrated from $5 \mu \mathrm{M}$ to $100 \mu \mathrm{M}$ for DTNB method and, using DLM linked to L-cysteine as standard, was from $0.1 \mu \mathrm{M}$ to $7.5 \mu \mathrm{M}$ for DLM method (Table 1).

3.2.1. Rituximab. Statistical analysis shows equality between Mabthera and Kikuzubam with $P$ values of 0.4022 and 0.8027 for DTNB and DLM methods, respectively. Cys/Rituximab average molar ratios of 0.602 and 0.558 with a confidence interval of $95 \%$ from 0.6977 to 0.5068 for Mabthera were obtained using DTNB method, while 1.149 and 1.076 average 
TABLE 3: Thiol quantification using DLM method. Rituximab and Etanercept free thiols under native and denaturing conditions using DLM method. Dispersion values are presented in SD $(n=9)$.

\begin{tabular}{lccccrr}
\hline Protein & Condition & Mabthera & RSD & Kikuzubam & RSD & $P$ \\
\hline \multirow{2}{*}{ Rituximab } & Native & $0.0636 \pm 0.028$ & 44.1 & $0.0683 \pm 0.033$ & 47.8 & 0.7499 \\
& Denaturing & $1.149 \pm 0.480$ & 41.8 & $1.076 \pm 0.508$ & 47.2 & 0.8027 \\
\hline \multirow{2}{*}{ Etanercept } & Condition & Enbrel & RSD & Infinitam & RSD & $P$ \\
& Native & $0.0844 \pm 0.017$ & 19.5 & $0.0477 \pm 0.020$ & 41.7 & $<0.001$ \\
& Denaturing & $1.091 \pm 0.207$ & 19.0 & $1.067 \pm 0.068$ & 6.4 & 0.7984 \\
\hline
\end{tabular}

TABLE 4: Specificity and accuracy of thiol analysis. Controls are specified for DTNB method and DLM method.

\begin{tabular}{lccc}
\hline Protein & Condition & \multicolumn{2}{c}{ Cys/Protein molar ratio } \\
& & DTNB & DLM \\
\hline Somatropin & Denaturing/reducing & $3.98 \pm 0.31$ & NT \\
\hline HSA & & $0.001 \pm 0.007$ & $1.01 \pm 0.17$ \\
Glatiramer acetate & Native & $0.0005 \pm 0.001$ & $0.045^{\mathrm{a}}$ \\
Placebo Rituximab & & $0.0005 \pm 0.001$ & $0.0004^{\mathrm{a}}$ \\
Placebo Etanercept & & $\mathrm{NT}$ & $0.0024^{\mathrm{a}}$ \\
Protein marker & & $0.0005^{\mathrm{a}}$ \\
\hline
\end{tabular}

NT: not tested.

${ }^{\mathrm{a}} \mathrm{SD}$ value is less than $1 \times 10^{-5}$.

molar ratios were obtained for Mabthera and Kikuzubam, respectively, using DLM method with a confidence interval from 1.7010 to 0.5973 for Mabthera (Tables 2 and 3).

3.2.2. Etanercept. Statistical equality was obtained for Enbrel and Infinitam with $P$ values of 0.2450 and 0.7983 using DTNB and DLM methods, respectively. Cys/Etanercept mean molar ratios of 0.447 and 0.498 for Enbrel and Infinitam, respectively, with a confidence interval at $95 \%$ from 0.5388 to 0.3548 for Enbrel, were obtained with DTNB method. Mean molar ratios of 0.7787 and 0.7618 using DLM method were obtained for Enbrel and Infinitam, respectively, with a confidence interval at $95 \%$ from 0.9488 to 0.6087 for Enbrel (Tables 2 and 3 ).

3.3. Denaturing-Reducing Conditions. Unlike native or denaturing conditions, the analysis of free thiols under denaturing-reducing conditions is a direct measure of the total cysteines residues within the protein. Somatropine CRS was used as positive control to verify the measurement, with an expected Cys/Somatropine mean molar ratio of 4 (Table 4).

3.3.1. Rituximab. The expected number of cysteine residues in Rituximab, as an IgG isotype I, is 32. DTNB method results for Mabthera and Kikuzubam were $31.6 \pm 0.8$ and $30.8 \pm 1.5$, respectively. Statistical analysis showed a $P$ value of 0.1475 between products with a confidence interval at $95 \%$ from 32.3 to 31.0 for Mabthera (Table 2).

3.3.2. Etanercept. Theoretical content of cysteine residues in Etanercept according to the primary sequence is 58. DTNB method results for Enbrel and Infinitam under denaturingreducing conditions were $56.6 \pm 2.5$ and $58.9 \pm 1.4$, respectively.
Statistical analysis reveals a $P$ value of 0.0229 with a confidence interval at $95 \%$ from 58.6 to 56.6 for Enbrel (Table 2).

3.4. Method Validation. Characteristics were chosen for method validation, according to ICH Q2 R1 guideline [25]. DTNB method, complied with all the previously designed acceptance criteria, was based on results obtained during analytical development. Validation results are summarized in Table 1.

Repeatability results show better performance for DLM method than for DTNB method under native conditions; RSD was decreased from $17.3 \%$ to $13.3 \%$. Also 20 times less protein concentration was used $\left(1 \mathrm{mg} \cdot \mathrm{mL}^{-1}\right.$ instead of $\left.20 \mathrm{mg} \cdot \mathrm{mL}^{-1}\right)$ and a lower quantification limit $(5 \mu \mathrm{M}$ to $0.1 \mu \mathrm{M}$ ) was observed (Table 1 ).

Linearity was evaluated using the solution buffers according to the different conditions (native and denaturing; for denaturing-reducing conditions samples were previously buffer exchanged with native conditions' buffer) as components can affect standard curve slopes. Calibration curve slopes for cysteine standard using DTNB method under denaturing conditions and native conditions showed a difference of $27.3 \%$ (Table 1 ).

Calculated recovery percentage under denaturingreducing conditions, using Somatropine CRS, was 99.5\% for DTNB method. Calculated recovery percentage under native conditions, using HSA, for DLM method was $101.0 \%$ (Table 4).

\section{Discussion}

Analysis of free thiol groups under native conditions of the evaluated Rituximab products (Kikuzubam and Mabthera) 
TABle 5: DyLight Maleimide method and nonspecific interactions tests under native conditions.

\begin{tabular}{lcccc}
\hline Protein & $\begin{array}{c}1 \\
\text { Thiol quantification } \\
\text { by DLM method }\end{array}$ & $\begin{array}{c}\text { Nonspecific interaction } \\
\text { (DLM neutralization) }\end{array}$ & $\begin{array}{c}\text { Protein amine neutralization } \\
\text { (protein isothiocyanate treatment) }\end{array}$ & $\begin{array}{c}\text { Thiol quantification } \\
\text { by DTNB Method }\end{array}$ \\
\hline A Rituximab & $0.0632 \pm 0.0274$ & $0.0230 \pm 0.0001$ & $0.0426 \pm 0.0094$ & $0.0180 \pm 0.0032$ \\
B Etanercept & $0.0965 \pm 0.0028$ & $0.0349 \pm 0.0000$ & $0.0229 \pm 0.0000$ & $0.0240 \pm 0.0049$ \\
C Glatiramer acetate & $0.0450 \pm 0.0000$ & $0.0001 \pm 0.0001$ & $0.0026 \pm 0.0000$ & $0.0010 \pm 0.0024$ \\
\hline
\end{tabular}

showed equivalent Cys/Protein molar ratios, for DLM $(P=$ $0.7499)$ and DTNB method $(P=0.6233)$, suggesting that both molecules have comparable structures and physicochemical integrity [26] (Tables 2 and 3).

Cys/Protein molar ratios within the range of 0.010 to 0.020 have been reported for therapeutic mAb's under native conditions using DTNB as derivatizing agent [26]. These values, derived from current commercial products, predicted to maintain biological, physicochemical, and structural integrity, can be used as a reference range, where the preservation of the folded structure inhibits the exposure of sulfhydryl groups and their oxidation to sulfenic, sulfinic, or sulfonic groups while restraining disulfide bridges cleavage. Cys/Protein molar ratios of Rituximab products, using DTNB method, rely within the aforementioned range, with 0.020 and 0.018 for Kikuzubam and Mabthera, respectively (Table 2). However, DLM method revealed higher Cys/ Protein molar ratios, although comparability between products was confirmed, with 0.068 and 0.064 for Kikuzubam and Mabthera, respectively (Table 3). The enhancement of fluorescence was expected from DLM noncovalent interactions towards hydrophobic patches within the protein or by the covalent reaction against amine substituents [27], although DLM reaction against primary amines was diminished using a low DLM concentration [27] and a buffer at $\mathrm{pH}<7.5$ [20]. Nevertheless, DLM method results for glatiramer acetate (thiol-free peptide), used as a negative control, revealed that fluorescence response was only reduced at placebo-response levels after phenylisothiocyanate titration against its amine groups (Table 5). It was possible to make this phenomenon evident because of the basic nature and high lysine concentration of glatiramer acetate ( $\mathrm{pI}$ around 10.5), showing a Cys/Protein molar ratio of 0.045 under native conditions, far from the 0.003 ratio after amine neutralization, where DLM-amine interactions were avoided and expected null response was obtained (Table 5). Nonspecific interactions of DLM were tested using cysteine to neutralize DLM prior contact with protein, resulting in a Cys/Protein molar ratio $<0.001$ for glatiramer acetate, under native conditions, which is an indicative of absence of those interactions (Table 5). Instead, Cys/Protein molar ratios from Rituximab and Etanercept tested with cysteine neutralized DLM were 0.023 and 0.035 , respectively, enlightening a protein-specific DLM interaction, related to three-dimensional conformation, polarity, and electrical charge. Overall, this explains the high Cys/Protein molar ratios observed for DLM method and the unsuitability of arithmetical corrections. It is worth to mention that Maleimide artifacts are major drawbacks of DLM method, although the fundamental
TABLE 6: Biological potency for Etanercept and Rituximab products.

\begin{tabular}{lcc}
\hline Product & Batch number & Biological potency (\%) \\
\hline \multirow{3}{*}{ Infinitam } & ETPP12001 & 106 \\
& ETPP12003 & 101 \\
& ETPP12005 & 110 \\
\hline \multirow{3}{*}{ Kikuzubam } & 5445110403 & 106 \\
& 5433120509 & 96 \\
\hline
\end{tabular}

${ }^{\mathrm{a}}$ Biological potency measured by TNF-alfa neutralization relative to Enbrel.

${ }^{\mathrm{b}}$ Biological potency measured by CDC relative to Mabthera.

reasons need to be understood and overcome, which is out of the scope of this paper.

Under denaturing conditions, Cys/Protein molar ratios of both Rituximab products show no statistical difference, using DLM $(P=0.8027)$ and DTNB methods $(P=0.4022)$. This confirmed structural similarity among products because of the content of buried thiol substituents, coming from nonbonded or broken disulfide bridges [28], revealing the same susceptibility towards degradation (Tables 2 and 3). Although, under denaturing conditions, Cys/Protein molar ratios are 15 to 30 times higher than native conditions (Tables 2 and 3), no impact in the biological activity of Rituximab products was detected (Table 6). This is in accordance with published data that shows no impact on the biological activity of a mAb that binds CD20 containing unpaired cysteines [28].

Once fully denatured and reduced, 32 exposed cysteine residues are expected in Rituximab according to its primary sequence. Cys/Protein molar ratio measurements, under denaturing-reducing conditions using DTNB method, showed that Mabthera and Kikuzubam are comparable $(P=$ 0.1475 ) and have a mean value of 31.6 and 30.8 cysteine residues, respectively (Table 2 ). Kikuzubam difference against the theoretical value $(3.8 \%)$ relies within the RSD of the method (Table 1).

Quantitation of buried thiol substituents that come from broken and unpaired disulfide bridges or the total cysteine content within denatured and denatured-reduced Rituximab products, respectively, was suggested from structural analysis by CD spectra. As seen from Figure 1 Rituximab secondary structure (far CD-UV spectra), that comprises mainly domains of two beta sheets linked by a disulfide bridge and compressed by $\beta$-antiparallel barrel [29], was lost when treated with both denaturing and reducing agents. This was also observed for tertiary structure response (near CD-UV spectra), as signal from native condition was diminished 


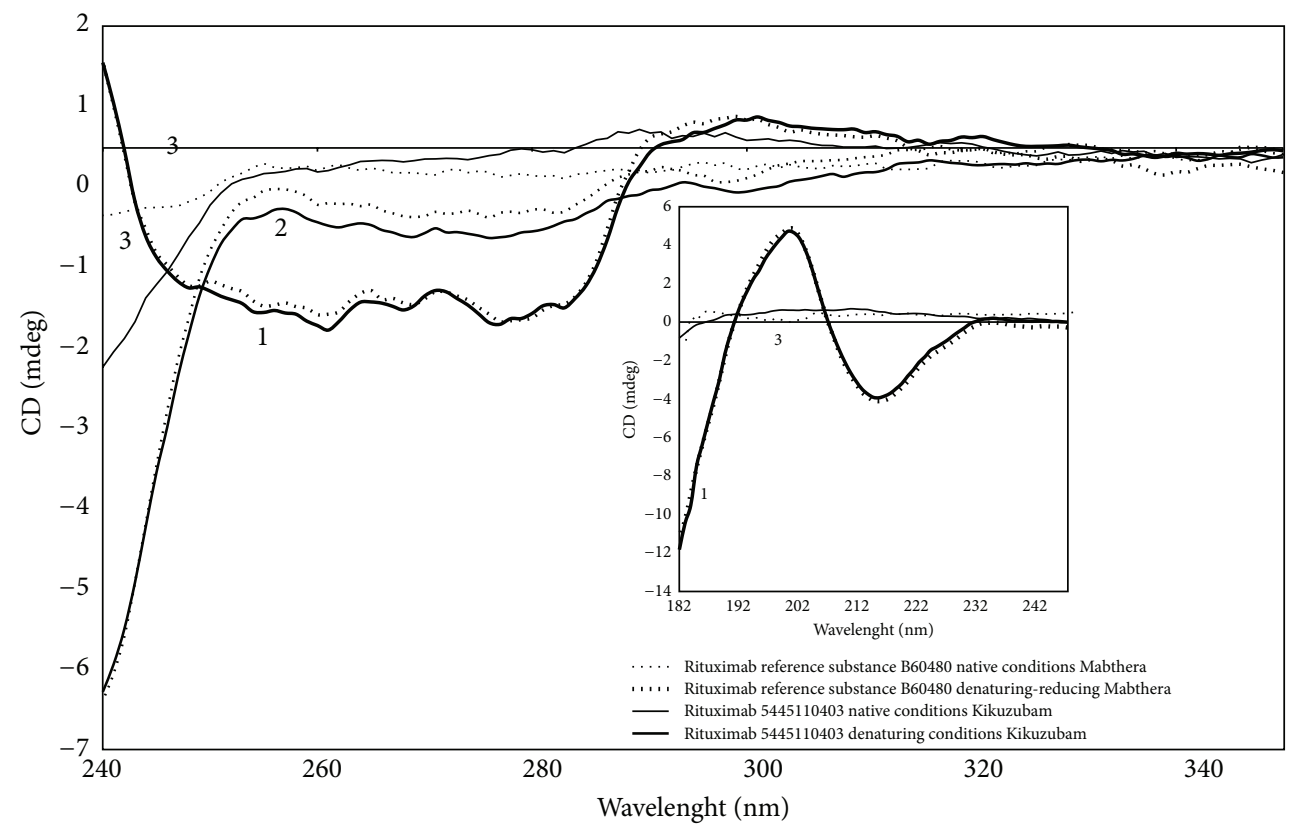

..... Rituximab reference substance B60480 native conditions Mabthera

..... Rituximab reference substance B60480 denaturing conditions Mabthera

...... Rituximab reference substance B60480 reducing-denaturing conditions Mabthera

— Rituximab 5445110403 native conditions Kikuzubam

— Rituximab 5445110403 denaturing conditions Kikuzubam

— Rituximab 5445110403 denaturing-reducing conditions Kikuzubam

(a)

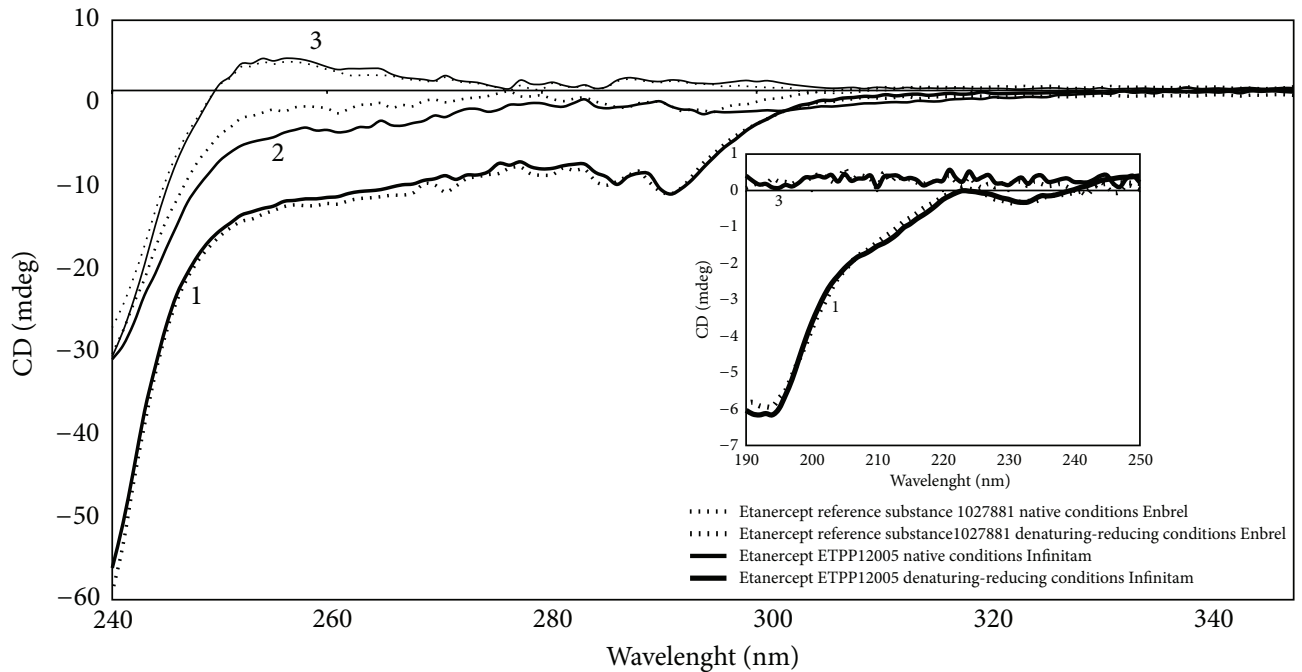

.... Etanercept reference substance G18414 native conditions Enbrel

.... Etanercept reference substance G18414 denaturing conditions Enbrel

.... Etanercept reference substance G18414 reducing-denaturing conditions Enbrel

- Etanercept ETPP12001 native conditions Infinitam

- Etanercept ETPP12001 denaturing condition Infinitam

- Etanercept ETPP12001 reducing-denaturing condition Infinitam

(b)

FIGURE 1: Far- and near-UV CD spectra of (a) Rituximab and (b) Etanercept products under (1) native, (2) denaturing, and (3) denaturingreducing conditions. Dotted lines represent Mabthera (Rituximab) and Enbrel (Etanercept), while continuous lines represent Kikuzubam (Rituximab) and Infinitam (Etanercept) representative batches. Main plot shows near-UV CD spectra (240-350 nm) and graphic insert shows far-UV CD spectra (190-300 nm). Near- and Far-UV characteristic spectra of Rituximab are shown in (a) and insert shows antiparallel $\beta$ sheets coming from $\mathrm{CH}_{1}, \mathrm{CH}_{2}$, and $\mathrm{CH}_{3}$ and $\mathrm{V}_{\mathrm{L}}$ and $\mathrm{V}_{\mathrm{H}}$ domains. Etanercept spectra (b) show an irregular structure directed probably by complex and diverse glycan substituents. Each sample was run in triplicate; average is represented as single spectrum (details are described in Section 2.3.6). 
under denaturing conditions and lost when Rituximab was treated with a reducing agent, thus confirming structural similarity among Rituximab products.

CD analyses for Etanercept also confirmed structural similarity among the evaluated products, Infinitam and Enbrel, revealing comparable loss of structure from native to denaturing-reducing conditions for near CD-UV and far CDUV spectra (Figure 1). Thiol analysis under native conditions, using DLM method, showed a higher content of free and exposed thiols for Enbrel than Infinitam, while DTNB method showed no statistical difference between Cys/Protein molar ratios of Etanercept products $(P=0.0758)$ (Tables 2 and 3). Statistical analysis of Cys/Protein molar ratios for DLM method revealed a $P$ value $<0.001$, suggesting a higher amount of denatured molecules in Enbrel batches or different glycosylation patterns that could affect thiol determination (steric hindrance). However intrinsic Trp fluorescence lifetime (Table 7) and biological activity through TNF- $\alpha$ neutralization assays (Table 6) revealed no significant differences among products. These results make evident the same DLM artifacts seen for Rituximab and glatiramer acetate, mostly relevant for the measure of Cys/Protein molar ratios $<1.0$. Actually, under denaturing conditions, statistical equality was observed using DLM $(P=0.7984)$ and DTNB $(P=0.2450)$ methods.

For the analysis of Etanercept products, under reducing conditions, samples were previously desialylated with neuraminidase in order to avoid the electrostatic repulsion of DTNB dye against sialic acids and to diminish steric hindrance effects that could came from the high glycan density of Etanercept (up to 30\% of the total molecular mass) and its high negative charge density ( 0.1 to 0.2 nmoles of sialic acids per mole of Etanercept). Neuraminidase treatment improved the measurement from the initially obtained Cys/Protein mean molar ratio around 20, far from the expected value of 58, to mean molar ratios of 56.6 and 58.9 for Enbrel and Infinitam, respectively. Enbrel difference against the expected value was $2.5 \%$; thus it is meaningless to establish a difference among products, despite the fact that both groups are not statistically equal $(P=0.0229)$. These results show that both products are comparable based on their equal behavior. Thus differences against theoretical values of Rituximab and Etanercept products are due to sample properties, possibly due to their vulnerability to be oxidized, although degassing of dissolved oxygen for all buffers solutions was performed. However, the observed difference in both pharmaceutical ingredients is lower than the RSD of the method (Tables 2 and 3 ).

Validation of DLM and DTNB methods complies with the specified acceptance criteria (Table 1). Specificity test for DTNB method using glatiramer acetate (negative control) showed a mean absorbance of 0.0014 , around 10 times below than Etanercept under native conditions, thus being acceptable and confirmatory of all results (Table 4). For DLM method the use of glatiramer acetate was not possible because of nonspecific reactions. $10 \mathrm{kDa}$ protein marker was proved to be suitable as negative control, but absolute Cys/Protein mean molar ratios need to be taken carefully when being $<1.0$; although being repeatable (RSD 17.3\%) and consistent, still
TABLE 7: Intrinsic Trp fluorescence lifetime measure using TCSPC for Etanercept products. Dispersion values are presented in SD $(n=$ 9).

\begin{tabular}{lcc}
\hline Product & Seconds $(\mathrm{s})$ & $P$ \\
\hline Enbrel & $1.30 E-09 \pm 6.24 E-12$ & 0.2784 \\
Infinitam & $1.29 E-09 \pm 8.98 E-12$ & \\
\hline
\end{tabular}

they are beneath the artifacts values. It is worth to mention that high RSD for DTNB and DLM, in Tables 2 and 3, comes mainly from batch to batch variability than method uncertainty; therefore they can be useful for measured dispersion between batches and also in new molecules process development.

Accuracy for DTNB method under denaturing-reducing conditions was assured using Somatropine CRS as positive control; results showed a Cys/Protein mean molar ratio of 3.98 , which corresponds to the theoretical value of $4(99.5 \%$ recovery) (Table 4). Measurements with DLM method, using HSA as positive control, proved to be accurate around the theoretical value of 1 (101.0\% recovery), which is above nonspecific DLM-protein values (Tables 4 and 5). Validation results are summarized in Table 1.

Therefore, orthogonal DLM and DTNB methodologies showed that structural integrity of biopharmaceuticals produced by different manufacturers is comparable, Kikuzubam versus Mabthera and Infinitam versus Enbrel, respectively. Spectroscopic methods confirmed these results.

During method development several drawbacks were identified and some overcame; these arise mainly from the lack of detailed descriptions in the published procedures; Issues, causes, and solutions are listed in a troubleshooting guide (Table 8) that highlights aspects of the methodology here described.

\section{Conclusions}

DTNB and DLM methods were proven to be suitable according to validation results for the characterization and comparability analyses of free thiol groups in biopharmaceuticals, whereas DLM method showed to be at least 50 times more sensitive than DTNB method (demonstrated by comparison of curves, quantitation limit). However, it could not be used in the low range thiol quantification because several interactions of DLM towards protein amines and hydrophobic patches are present.

Using both techniques, comparability between Rituximab and Etanercept products coming from different manufacturers was proved for thiol analysis under native, denaturing, and denaturing-reducing conditions and confirmed by CD, TCSPC, and biological activity assays. Each selected condition was chosen as a measure of the protein either: intact, denatured without disulfide bridges disruption, or denatured reduced with all its thiol substituents exposed.

Nowadays, to the best of our knowledge, several studies report the use of DTNB and DLM methods for different purposes; however in this study we recommended some suggestions to reduce variability of measurements, high back- 
TABLE 8: Troubleshooting for DTNB and DyLight 488 Maleimide methods.

\begin{tabular}{|c|c|c|}
\hline Problem & Cause & Solution \\
\hline \multicolumn{3}{|c|}{ Native conditions } \\
\hline \multirow{2}{*}{$\begin{array}{l}\text { High variability on } \\
\text { measurements. }\end{array}$} & Low protein quantity. & $\begin{array}{l}\text { Increase protein concentration to } \\
20-30 \mathrm{mg} \cdot \mathrm{mL}^{-1} \text {. }\end{array}$ \\
\hline & Samples homogeneity. & Always vortex protein solutions. \\
\hline High background. & Particles in buffer solution. & $\begin{array}{l}\text { Filter buffer solutions through } 0.2 \mu \mathrm{m} \\
\text { hydrophilic membrane. }\end{array}$ \\
\hline \multirow[t]{2}{*}{ High sulfhydryl measurement. } & Sample stress. & $\begin{array}{l}\text { Avoid high temperatures and analyze samples } \\
\text { within } 12 \text { hours once prepared. Dialyze samples } \\
\text { at } 4^{\circ} \mathrm{C} \text {. }\end{array}$ \\
\hline & Sample excipients interference. & Dialyze samples against water. \\
\hline \multicolumn{3}{|c|}{ Denaturing conditions } \\
\hline Low sulfhydryl measurement & pH lower than 6.5 . & $\begin{array}{l}\text { Verify buffer solution } \mathrm{pH} \text { after } \mathrm{GdnHCl} \\
\text { addition. }\end{array}$ \\
\hline \multirow{3}{*}{$\begin{array}{l}\text { High sulfhydryl measurement } \\
\text { using DyLight } 488 \text { Maleimide. }\end{array}$} & pH higher than 7.5 . & $\begin{array}{l}\text { Verify buffer solution } \mathrm{pH} \text { after } \mathrm{GdnHCl} \\
\text { addition. }\end{array}$ \\
\hline & Overincubation. & $\begin{array}{l}2 \text { hours of incubation must be enough for } \\
\text { derivatization. }\end{array}$ \\
\hline & Incomplete dialysis. & Increase dialysis time and buffer exchange. \\
\hline \multicolumn{3}{|c|}{ Denaturing-reducing conditions } \\
\hline Low sulfhydryl measurement. & Oxidized thiols. & $\begin{array}{l}\text { Degasify all buffer solutions by sonication } \\
\text { during } 30 \text { min and nitrogen bubbling during } \\
2-15 \text { min prior its use. }\end{array}$ \\
\hline $\begin{array}{l}\text { High background at } 280 \mathrm{~nm} \\
\text { using DTNB. }\end{array}$ & TNB interference. & $\begin{array}{l}\text { Estimate protein concentration prior } \\
\text { derivatization. }\end{array}$ \\
\hline
\end{tabular}

ground, over thiol quantification and also increase the method sensitivity in order to have successful method performance. Previous information has been used to overcome drawbacks. Here we reported the capabilities of both colorimetric and fluorometric methods to determine free reactive thiols under different protein conditions, in order to demonstrate the protein structural correspondence between biosimilars and innovator drug products.

\section{Conflict of Interests}

The authors Víctor Pérez-Medina-Martínez, Alexis J. Romero-Díaz, Néstor O. Pérez, Luis F. Flores-Ortiz, and Emilio Medina-Rivero are employees of Probiomed S.A. de C.V., which is developing, manufacturing, and marketing biosimilar products. These authors are involved in the development of biosimilar products for Probiomed. The authors Mario E. Abad-Javier and Francisco Villaseñor-Ortega declare no conflict of interests.

\section{Acknowledgments}

This work was supported by CONACYT, Mexico, Grant FINNOVA 174104. Thanks are due to Miriam Cedillo for bioassay information and method development.

\section{References}

[1] D. G. Maloney, A. J. Grillo-López, C. A. White et al., "IDECC2B8 (Rituximab) anti-CD20 monoclonal antibody therapy in patients with relapsed low-grade non-Hodgkin's lymphoma," Blood, vol. 90, no. 7, pp. 2188-2195, 1997.

[2] L. W. Moreland, "Soluble tumor necrosis factor receptor (p75) fusion protein (Enbrel) as a therapy for rheumatoid arthritis," Rheumatic Disease Clinics of North America, vol. 24, no. 3, pp. 579-591, 1998.

[3] N. Nagahara, "Catalytic site cysteines of thiol enzyme: sulfurtransferases," Journal of Amino Acids, vol. 2011, Article ID 709404, 7 pages, 2011.

[4] C. S. Sevier and C. A. Kaiser, "Formation and transfer of disulphide bonds in living cells," Nature Reviews Molecular Cell Biology, vol. 3, no. 11, pp. 836-847, 2002.

[5] Y. K. Lee, J. W. Brewer, R. Hellman, and L. M. Hendershot, "BiP and immunoglobulin light chain cooperate to control the folding of heavy chain and ensure the fidelity of immunoglobulin assembly," Molecular Biology of the Cell, vol. 10, no. 7, pp. 22092219, 1999.

[6] J. L. Cleland, M. F. Powell, and S. J. Shire, "The development of stable protein formulations: a close look at protein aggregation, deamidation, and oxidation," Critical Reviews in Therapeutic Drug Carrier Systems, vol. 10, no. 4, pp. 307-377, 1993.

[7] J. M. Pikal, K. M. Dellerman, M. L. Roy, and R. M. Riggin, “The effects of formulation variables on the stability of freeze-dried human growth hormone," Pharmaceutical Research, vol. 8, no. 4, pp. 427-436, 1991. 
[8] C. N. Pace, F. Vajdos, L. Fee, G. Grimsley, and T. Gray, "How to measure and predict the molar absorption coefficient of a protein," Protein Science, vol. 4, no. 11, pp. 2411-2423, 1995.

[9] L. M. Powell and R. H. Pain, "Effects of glycosylation on the folding and stability of human, recombinant and cleaved $\alpha 1-$ antitrypsin," Journal of Molecular Biology, vol. 224, no. 1, pp. 241252, 1992.

[10] H. Kahlert, R. Suck, B. Weber et al., "Characterization of a hypoallergenic recombinant Bet v 1 variant as a candidate for allergen-specific immunotherapy," International Archives of Allergy and Immunology, vol. 145, no. 3, pp. 193-206, 2008.

[11] G. Ellman, "Tissue sulfhydryl groups," Archives of Biochemistry and Biophysics, vol. 82, no. 1, pp. 70-77, 1959.

[12] E. A. Nalefski, C. M. D’Antoni, E. P. Ferrell et al., "Single-molecule detection for femtomolar quantification of proteins in heterogeneous immunoassays," Clinical chemistry, vol. 52, no. 11, pp. 2172-2175, 2006.

[13] T. Rispens, P. Ooijevaar-de Heer, N. I. Derksen, G. Wolbink, P. A. van Schouwenburg, and S. Kruithof, "Nanomolar to subpicomolar affinity measurements of antibody-antigen interactions and protein multimerizations: fluorescence-assisted highperformance liquid chromatography," Analytical Biochemistry, vol. 437, no. 2, pp. 118-122, 2003.

[14] C. Zhang, C. Rodriguez, M. L. Circu, T. Y. Aw, and J. Feng, "S-glutathionyl quantification in the attomole range using glutaredoxin-3-catalyzed cysteine derivatization and capillary gel electrophoresis with laser-induced fluorescence detection," Analytical and Bioanalytical Chemistry, vol. 401, no. 7, pp. 21652175, 2011.

[15] S. M. Kelly, T. J. Jess, and N. C. Price, "How to study proteins by circular dichroism," Biochimica et Biophysica Acta, vol. 1751, no. 2, pp. 119-139, 2005.

[16] V. Kayser, N. Chennamsetty, V. Voynov, B. Helk, and B. L. Trout, "Tryptophan-tryptophan energy transfer and classification of tryptophan residues in proteins using a therapeutic monoclonal antibody as a model," Journal of Fluorescence, vol. 21, no. 1, pp. 275-288, 2011.

[17] X. Li, J. Link, S. Stekhova et al., "Site-specific labeling of annexin V with F-18 for apoptosis imaging," Bioconjugate Chemistry, vol. 19, no. 8, pp. 1684-1688, 2008.

[18] E. Wischerhoff, K. Uhlig, A. Lankenau et al., "Controlled cell adhesion on PEG-based switchable surfaces," Angewandte Chemie, vol. 47, no. 30, pp. 5666-5668, 2008.

[19] G. D. Smyth, A. Nagamatsu, and J. S. Fruton, "Some reactions of N-ethylmaleimide," Journal of the American Chemical Society, vol. 82, no. 17, pp. 4600-4604, 1960.

[20] D. G. Smyth, O. O. Blumenfeld, and W. Konigsberg, "Reactions of N-ethylmaleimide with peptides and amino acids," Biochemical Journal, vol. 91, no. 3, pp. 589-595, 1964.

[21] J. D. Marshall, W. C. Eveland, and C. W. Smith, "Superiority of fluorescein isothiocyanate (Riggs) for fluorescent-antibody technic with a modification of its application," Proceedings of the Society for Experimental Biology and Medicine, vol. 98, no. 4, pp. 898-900, 1958.

[22] R. J. Brezski, A. Oberholtzer, B. Strake, and R. E. Jordan, “The in vitro resistance of IgG2 to proteolytic attack concurs with a comparative paucity of autoantibodies against peptide analogs of the IgG2 hinge," $m A b s$, vol. 3, no. 6, pp. 558-567, 2011.

[23] T. Espevik and J. Nissen-Meyer, "A highly sensitive cell line, WEHI 164 clone 13, for measuring cytotoxic factor/tumor necrosis factor from human monocytes," Journal of Immunological Methods, vol. 95, no. 1, pp. 99-105, 1986.
[24] K. J. Grattendick, J. M. Nakashima, L. Feng, S. N. Giri, and S. B. Margolin, "Effects of three anti-TNF- $\alpha$ drugs: etanercept, infliximab and pirfenidone on release of TNF- $\alpha$ in medium and TNF$\alpha$ associated with the cell in vitro," International Immunopharmacology, vol. 8, no. 5, pp. 679-687, 2008.

[25] ICH Harmonized Tripartite Guideline, Validation of Analytical Procedures: Text and Methodology, Secretariat, Geneva, Switzerland, 2005.

[26] W. Zhang and J. Czupryn, "Free sulfhydryl in recombinant monoclonal antibodies," Biotechnology Progress, vol. 18, no. 3, pp. 509-513, 2002.

[27] C. F. Brewer and J. P. Riehm, "Evidence for possible nonspecific reactions between N-ethylmaleimide and proteins," Analytical Biochemistry, vol. 18, no. 2, pp. 248-255, 1967.

[28] T. Zhang, J. Zhang, D. Hewitt et al., "Identification and characterization of buried unpaired cysteines in a recombinant monoclonal IgG1 antibody," Analytical Chemistry, vol. 84, no. 16, pp. 7112-7123, 2012.

[29] J. P. Derrick and D. B. Wigley, "Crystal structure of a streptococcal protein G domain bound to an Fab fragment," Nature, vol. 359, no. 6397, pp. 752-754, 1992. 

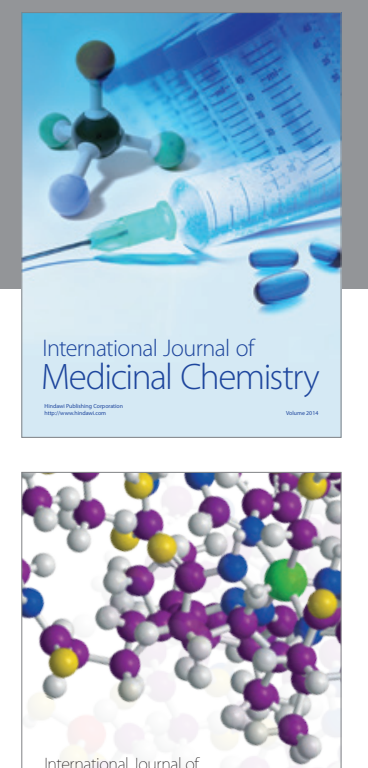

\section{Carbohydrate} Chemistry

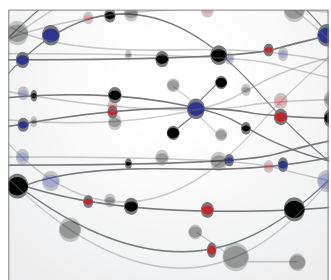

The Scientific World Journal
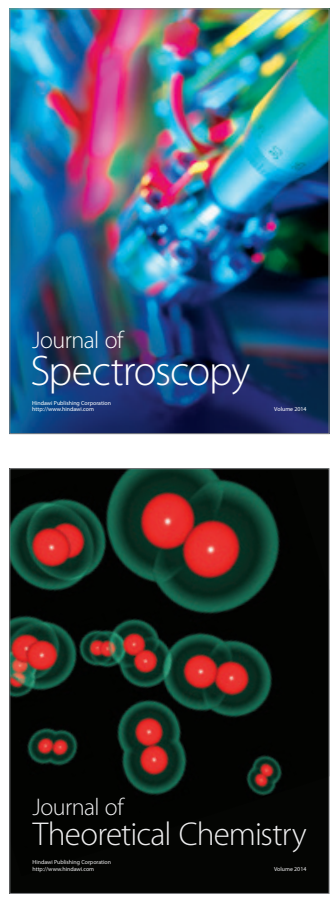
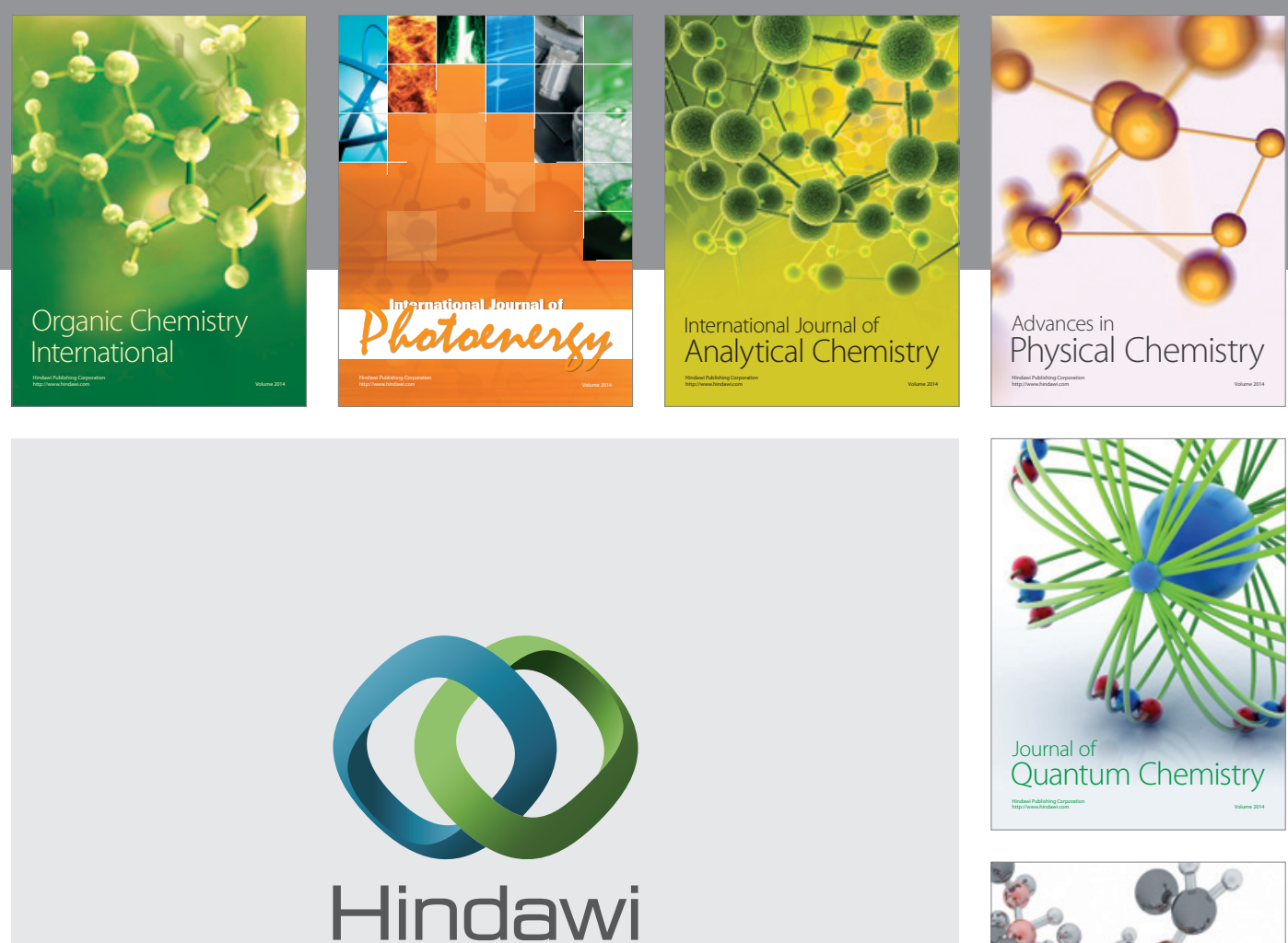

Submit your manuscripts at

http://www.hindawi.com

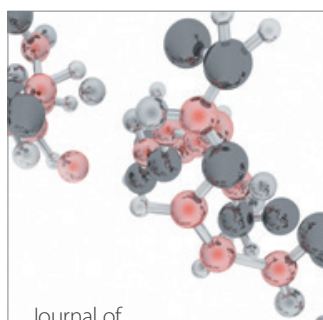

Analytical Methods

in Chemistry

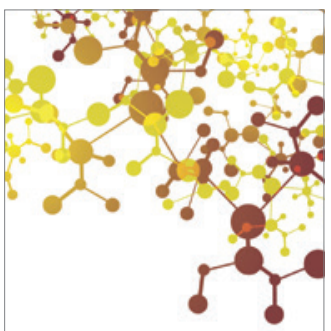

Journal of

Applied Chemistry

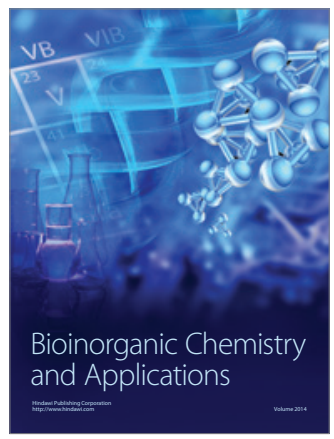

Inorganic Chemistry
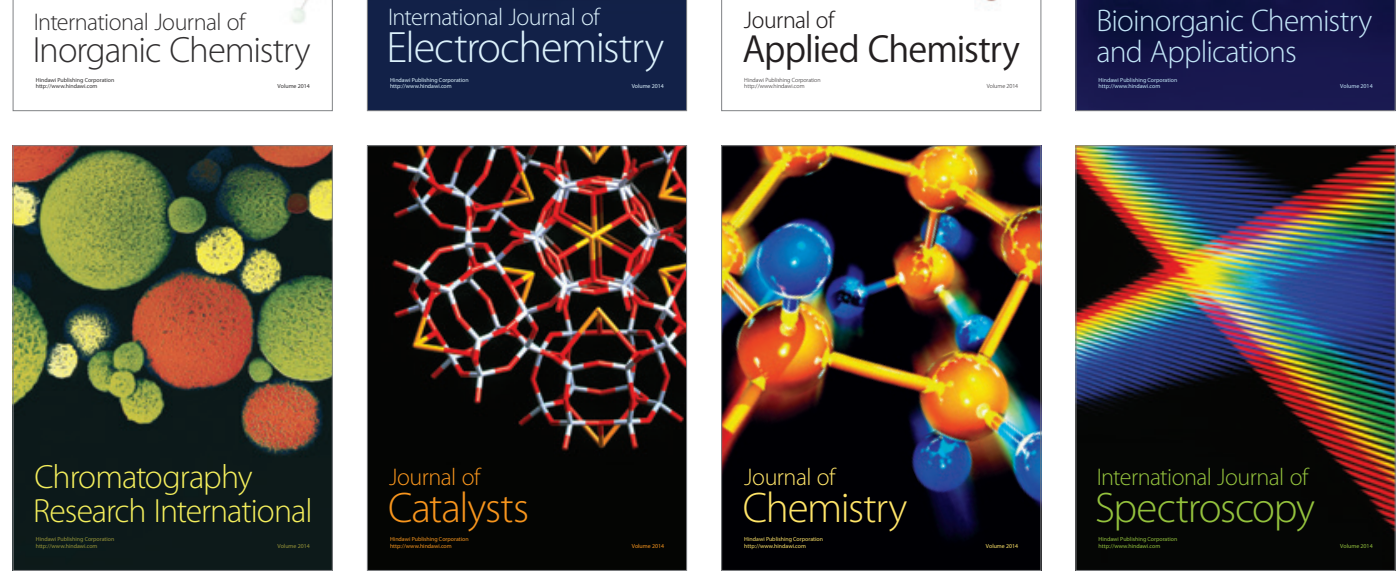